\title{
Implementasi Praktik Corporate Social Responsibility PT Pertamina Hulu Mahakam Melalui Program Pemberdayaan Nelayan
}

\author{
RSDMG Luhur $^{1}$ Ahmad Yuli ${ }^{1}$, Silmi Hadiyana ${ }^{*}$ \\ ${ }^{1}$ PT Pertamina Hulu Mahakam, \\ Jalan Yos Sudarso, Jl. Karang Jati Dalam No.1, Kota Balikpapan, 7611 \\ Email Penulis Korespodensi: silmihadiyana@gmail.com
}

\begin{abstract}
PT Pertamina Hulu Mahakam is a company engaged in upstream oil and gas for the Mahakam working area. The company's operations, which are mostly offshore, often come into contact with fishermen. Fishermen consider the collation of offshore platforms to be where they look for fish. Despite knowing there is a potential danger, fishermen continue to search for fish around the platform. The form of social responsibility of PT Pertamina Hulu Mahakam for the impact of operations is realized through a NELAYANKU HEBAT program. The method used in this research is qualitative to know more details about the implementation of the NELAYANKU HEBAT program. This program was born not limited to launching the company's activities alone. But also as a form of concern of PT Pertamina Hulu Mahakam towards the empowerment of fishermen and environmental conservation around the operating area. During the three years running, various activities carried out in this program include; initiation of group formation, assistance, and training of fishery support technology, application of environmentally friendly fishing practices using rumpon, welding training, and training on the processing of fishery products. To improve the quality of the program, PT Pertamina Hulu Mahakam conducts accompaniment, monitoring, and evaluation periodically. So far the results felt by fishermen from this program are the increasing economy of families, increased skills, increased awareness of environmental preservation, and increased productivity of wives.
\end{abstract}

Keywords: PT Pertamina Hulu Mahakam, Empowerment, CSR

\begin{abstract}
Abstrak
PT Pertamina Hulu Mahakam merupakan perusahaan yang bergerak di bidang hulu minyak dan gas untuk wilayah kerja Mahakam. Aktivitas operasi perusahaan mayoritas berada di lepas pantai dan kerap bersinggungan dengan nelayan. Nelayan menganggap lokasi anjungan lepas pantai dahulunya sebagai tempat mereka mencari ikan. Meskipun sudah mengetahui adanya potensi bahaya, nelayan tetap beraktivitas mencari ikan di sekitar anjungan. Bentuk tanggung jawab sosial PT Pertamina Hulu Mahakam atas dampak operasi diwujudkan melalui program NELAYANKU HEBAT. Metode yang digunakan dalam penelitian ini adalah kualitatif dengan tujuan untuk mengetahui lebih detil mengenai implementasi program NELAYANKU HEBAT. Program ini lahir tidak sebatas untuk melancarkan kegiatan operasi perusahaan semata. Tetapi juga sebagai bentuk kepedulian PT Pertamina Hulu Mahakam terhadap pemberdayaan nelayan dan pelestarian lingkungan sekitar wilayah operasi. Selama tiga tahun berjalan, berbagai kegiatan yang dilakukan pada program ini antara lain; inisiasi pembentukan kelompok, bantuan dan pelatihan teknologi penunjang perikanan, penerapan praktik nelayan ramah lingkungan menggunakan rumpon, pelatihan pengelasan, dan pelatihan pengolahan hasil produk perikanan. Demi meningkatkan kualitas program, PT Pertamina Hulu Mahakam melakukan pendampingan, monitoring dan evaluasi secara berkala. Sejauh ini hasil yang dirasakan oleh nelayan dari program ini adalah meningkatnya perekonomian keluarga, meningkatnya keterampilan, meningkatnya kesadaran akan pelestarian lingkungan, dan meningkatnya produktivitas istri nelayan.
\end{abstract}

Kata kunci: PT Pertamina Hulu Mahakam, Pemberdayaan Nelayan, CSR 


\section{PENDAhUluan}

Kawasan Delta Mahakam yang berada di wilayah Kabupaten Kutai Kartanegara memiliki potensi sumber daya alam yang melimpah. Selain dikenal sebagai penghasil udang berkualitas ekspor, kawasan ini juga menyimpan cadangan minyak dan gas terbesar di Indonesia. Sejak tahun 2018, perusahaan yang mengeksplorasi minyak dan gas di Delta Mahakam adalah PT Pertamina Hulu Mahakam (PHM). Pada tahun 2020, PT PHM mendapatkan minyak dan kondensat sebanyak 29,4 ribu barel per hari dan gas sebesar 605,5 juta kubik per hari.

Mayoritas kegiatan operasi PT PHM berada di daerah perairan atau dikenal dengan istilah offshore. Hal ini menyebabkan terjadinya konflik kepentingan antara PT PHM dan masyarakat, karena mayoritas pekerjaan masyarakat di kawasan Delta Mahakam, tepatnya di muara Sungai Mahakam adalah nelayan. Nelayan beranggapan bahwa kegiatan PT PHM mengganggu aktivitas nelayan dalam mencari ikan. Mereka terpaksa mencari ikan ke tempat yang lebih jauh. Sehingga biaya pengeluaran nelayan untuk membeli bahan bakar akan bertambah, tapi penghasilan masih belum menentu.

Keberadaan anjungan lepas pantai yang semula diprotes oleh nelayan justru dimanfaatkan sebagai tempat mencari ikan. Karakteristik dari anjungan lepas pantai dinilai mampu menarik banyak ikan untuk berkembang biak dan berkumpul tepat di bawah anjungan. Maka tidak heran apabila nelayan banyak memperoleh hasil tangkapan dari sana. Saat itu nelayan merasa bahwa keberadaan anjungan lepas pantai PT PHM tidak terlalu berpengaruh pada pendapatan hasil tangkapan mereka. Anjungan lepas pantai yang disebut oleh nelayan sebagai solusi justru menambah persoalan baru bagi PT PHM karena sekitar lokasi tersebut merupakan area terlarang dan berbahaya bagi siapapun. Potensi ledakan dan kebocoran pipa dapat merugikan negara, mencemari lingkungan dan mengancam keselamatan nelayan.

Potret persoalan yang dihadapi oleh PT PHM dengan nelayan yang berada di Selat Makassar merupakan bagian dari dinamika kehidupan masyarakat. Bukan hanya PT PHM, perusahaan di daerah lain pun tidak bisa terlepas dari prokontra dengan masyarakat yang berada di sekitar operasi perusahaan. Implikasi dari kegiatan perusahaan dipastikan mempengaruhi aspek sosial dan lingkungan.

Sejumlah regulasi mengenai Tanggung Jawab Sosial dan Lingkungan (TJSL) atau yang populer dengan istilah CSR (Corporate Social Responsibility) telah dikeluarkan oleh pemerintah di antaranya Undang-Undang Nomor 40 Tahun 2007 Tentang Perseroan Terbatas dan Peraturan Pemerintah Nomor 47 Tahun 2012 Tentang Tanggung Jawab Sosial dan Lingkungan Perseroan Terbatas. Inti dari regulasi-regulasi tersebut adalah perusahaan sebagai entitas bisnis harus bertanggung jawab kepada pihak-pihak yang secara langsung maupun tidak langsung terdampak atas aktivitas perusahaan, serta perusahaan wajib menciptakan hubungan yang serasi, seimbang dan sesuai dengan lingkungan, nilai, norma dan budaya masyarakat setempat.

PT Pertamina Hulu Mahakam sebagai anak perusahaan dari PT Pertamina (Persero) telah mengimplementasikan amanat terkait regulasi CSR. Komitmen tersebut dimanifestasikan ke dalam berbagai program dan kegiatan yang dibagi menjadi beberapa kategori, yakni charity, infrastruktur, lingkungan, capacity building, dan empowerment. Salah satu program unggulan PT PHM dalam mendukung pembangunan berkelanjutan di Indonesia adalah melalui Program Pemberdayaan Masyarakat (PPM) NELAYANKU HEBAT.

Program NELAYANKU HEBAT yang dalam tataran pelaksanaannya bersinergi dengan pemerintah, akademisi, dan masyarakat memiliki kegiatan utama yakni peningkatan ekonomi dan kapasitas nelayan melalui penguatan kelembagaan serta inovasi metode tangkap yang ramah terhadap lingkungan. Melalui program ini diharapkan terjadi perubahan status aktor nelayan yang semula kontra dan merasa dirugikan menjadi aktor yang mendukung kegiatan PT PHM. Selain itu, perilaku nelayan yang sifatnya short term menjadi lebih berkelanjutan, dari yang sebelumnya menggunakan alat tangkap tidak ramah lingkungan (pukat tarik) yang berpotensi menurunkan populasi ikan dan udang dalam jangka panjang berubah menjadi menggunakan alat tangkap yang lebih ramah lingkungan. Sesuai dengan akronim dari program NELAYANKU HEBAT ini, harapan terbesarnya adalah nelayan menjadi kuat, harmonis, berdaya dan bermartabat. 


\section{METODE}

\section{Waktu dan Tempat Pelaksanaan}

Pengaplikasian program NELAYANKU HEBAT dilakukan di Desa Muara Pantuan dan Desa Sepatin, Kecamatan Anggana, Kabupaten Kutai Kartanegara, Provinsi Kalimantan Timur. Waktu pelaksanaan pengabdian kepada masyarakat ini dilakukan mulai dari bulan Maret 2020 sampai bulan Desember 2020 (tahun ke-3 rencana strategis).

\section{Alat dan Bahan:}

Alat dan bahan yang digunakan dalam melaksanakan kegiatan ini adalah alat tulis, smartphone, formulir notulensi, monitoring dan evaluasi.

\section{Langkah Pelaksanaan}

Pelaksanaan program NELAYANKU HEBAT diinisiasi oleh PT PHM pada tahun 2018 sampai sekarang. Program ini memiliki rencana strategis (renstra) 5 tahunan yang dirincikan ke dalam rencana kerja (renja) satu tahunan. Itu berarti exit program akan dilakukan di tahun 2022. Tahapan penyusunan renja program NELAYANKU HEBAT setiap tahunnya memiliki pola yang sama yakni sebagai berikut;

\section{a. Tahap Perencanaan}

Meliputi kegiatan pemetaan sosial, Forum Komunikasi Masyarakat (FKM), penyusunan formulir Project Execution Plan (PEP), penyusunan dokumen rencana kerja, dan penyesuaian dokumen rencana strategis (jika ada). Semua program pemberdayaan masyarakat yang dimiliki oleh PT PHM selalu diawali oleh kegiatan FKM atau musyawarah dengan stakeholder-stakeholder terkait. Aini, dkk (2018) menjelaskan bahwa untuk menjalankan kehidupan bermasyarakat tidak pernah lepas dari proses interaksi sosial dan di dalam komunikasi sosial setiap individu tentu mempunyai pikiran, visi, dan misi yang berbeda.

\section{b. Tahap Implementasi}

Meliputi pelaksanaan kegiatan-kegiatan yang telah dicantumkan di dalam PEP dan rencana kerja tahunan. Progres capaian pelaksanaan kegiatan kemudian direkap ke dalam dokumen implementasi program. c. Tahap Monitoring dan Evaluasi

Meliputi kegiatan monitoring secara berkala setiap tiga bulan sekali dan untuk mengukur tingkat efektivitas kegiatan, dilakukan dua kali kegiatan evaluasi. Yaitu evaluasi tengah tahun dan evaluasi akhir tahun.

\section{HASIL DAN PEMBAHASAN}

Perkembangan zaman menuntut perusahaan untuk tidak hanya memperhatikan aspek keuntungan semata, tetapi juga kondisi sekitar yang di dalamnya terdapat aspek sosial dan lingkungan. Ketiga aspek tersebut dikenal sebagai Triple Bottom Line (TBL). Konsep TBL pertama kali diperkenalkan oleh John Elkington pada tahun 1994. Elkington (dalam Arowoshegbe \& Emmanuel, 2016) menyebutkan bahwa TBL merupakan konsep pengukuran kinerja suatu usaha secara holistik dengan memperhatikan ukuran kinerja ekonomis berupa perolehan keuntungan (profit), ukuran kepedulian sosial (people) dan pelestarian lingkungan (planet). Pilar dari konsep TBL di atas kemudian dijadikan pondasi bagi kegiatan CSR program NELAYANKU HEBAT.

\section{Aspek People}

Tujuan akhir dari program pengembangan masyarakat NELAYANKU HEBAT adalah menjadikan Desa Muara Pantuan dan Desa Sepatin sebagai destinasi wisata pancing dengan menempatkan nelayan sebagai objek sekaligus subjek pemberdayaan. Mulai tahun 2018 intervensi awal dari program ini adalah mendorong nelayan supaya menyatukan visi dan misi dengan cara berkelompok. Devito (1997) menjelaskan bahwa kelompok merupakan sekumpulan individu yang saling berhubungan dan berkomunikasi satu sama lain dengan beberapa tujuan yang sama dan di antara mereka terdapat struktur, norma, maupun peraturanperaturan.

Sebelum ada intervensi PT PHM, aktivitas nelayan di Desa Muara Pantuan dan Desa Sepatin dalam mencari ikan di laut mayoritas menggunakan alat tangkap trawl dan roppong. Roppong atau rumpon merupakan alat bantu penangkapan ikan. Rumpon membantu menarik gerombolan ikan agar berkumpul, nantinya nelayan dapat dengan mudah menangap ikan menggunakan pancing. 
Dalam satu bulan, hari efektif nelayan berlayar di Selat Makassar untuk mencari ikan sekitar 15 hari. Tanpa ada jaminan pasti memperoleh hasil tangkapan, nelayan tetap berlayar menyusuri lautan untuk mendapatkan ikan. Biaya pengeluaran Bahan Bakar Minyak (BBM) sekali melaut bisa menghabiskan 40 liter lebih. Jika dikonversi ke rupiah mencapai Rp280.000 (asumsi harga jual solar Rp7.000). Terkadang biaya, waktu, dan tenaga yang dikeluarkan tidak sebanding dengan hasil yang didapat.

Untuk meningkatkan efektifitas nelayan ketika mencari ikan, PT PHM melakukan familiarisasi teknologi penunjang kepada nelayan. Seperti Global Positioning System (GPS) dan fish finder. Manfaat yang diperoleh dengan adanya bantuan GPS terbagi menjadi dua, yakni manfaat secara langsung dan tidak langsung. Manfaat secara langsung yang dirasakan oleh nelayan adalah mereka tidak lagi mengalami "pencurian" ikan di rumpon. Karena tombak penanda lokasi rumpon telah diganti dengan titik koordinat GPS. Sehingga rumpon nelayan tidak diketahui keberadaannya oleh nelayan lain. Sedangkan manfaat tidak langsung dirasakan oleh PT PHM. Ketika rumpon nelayan dapat menghasilkan lebih banyak ikan, saat ini tidak ada nelayan yang tertarik untuk mendekat, menebar jaring dan memancing di sekitar anjungan. Sampai saat ini, respon nelayan terhadap bantuan peralatan tersebut yang disertai dengan pelatihan sangat positif. Bahkan mereka menganggap GPS dan fish finder yang mereka miliki lebih berharga dibanding emas.

Akhir tahun 2019 dunia digemparkan oleh temuan virus baru yang dinamakan virus corona (Covid-19). Di Indonesia kasus Covid-19 pertama kali teridentifikasi pada awal tahun 2020. Dampak Covid-19 sangat dirasakan oleh berbagai kalangan, termasuk kelompok nelayan (Kelompok Usaha Bersama/ KUB) binaan PT PHM. Harga ikan dan udang anjlok, harga kebutuhan pokok naik dan resiko tertular Covid19 merupakan dampak yang dirasakan langsung oleh masyarakat Desa Muara Pantuan dan Desa Sepatin. Melihat fenomena penyebaran Covid-
19 yang masif, PT PHM secara cepat melakukan tindakan penyesuaian renstra dan renja.

Penyesuaian kegiatan tahun 2020 menitikberatkan upaya daya tanggap terhadap bencana. Upaya memberikan perlindungan tidak hanya dilakukan kepada kelompok nelayan, tetapi mencakup juga keluarga nelayan, keluarga pra sejahtera dan masyarakat umum. Adapun aktivitas yang dilakukan meliputi pemberian sembako, masker, handsanitizer, tempat cuci tangan portable, dan alat tangkap ikan bagi nelayan tangkap dan nelayan budidaya. Pemberian bantuan alat tangkap di masa pandemi bertujuan untuk memangkas pengeluaran nelayan. Dengan memperlebar kegiatan pada program NELAYANKU HEBAT, penerima manfaat program tidak hanya tersentralisasi kepada nelayan.

Ketika harga ikan dan udang mengalami penurunan akibat pandemi disaat itu pula musim sedang paceklik atau istilah yang digunakan oleh masyarakat adalah musim ombak besar. Nelayan yang hanya mengandalkan satu profesi tidak memiliki aktivitas produktif lain yang menghasilkan pundi rupiah. Inisiatif PT PHM dengan cara mendirikan bengkel nelayan di tahun 2020 setidaknya mampu menambah peluang baru bagi nelayan untuk mendapatkan penghasilan tambahan di musim paceklik. Sebelumnya, PT PHM telah membekali nelayan dengan pelatihan pengelasan dan perbengkelan. Kini ilmu yang pernah mereka dapatkan bisa dipraktikkan di bengkel.

Keberadaan bengkel nelayan selain mampu menambah penghasilan, juga dapat mengurangi pengeluaran nelayan dalam membeli BBM. Karena sebelum adanya bengkel para nelayan menghabiskan BBM 25 liter hanya untuk memperbaiki kapal dan membeli perlengkapan kapal ke daerah darat yang ditempuh selama 2 jam perjalanan. Dengan demikian pengeluaran untuk operasional nelayan dapat diminimalisir berkat adanya GPS, fish finder, dan bengkel nelayan. Penghematan operasional BBM untuk melaut dan perbaikan kapal ke luar daerah dapat dilihat pada gambar di bawah ini. 


\begin{tabular}{|l|c|c|c|c|c|c|c|c|}
\hline \multirow{2}{*}{ Uraian } & \multicolumn{2}{|c|}{ Tahun 2017 } & \multicolumn{2}{c|}{ Tahun 2018 } & \multicolumn{2}{c|}{ Tahun 2019 } & \multicolumn{2}{c|}{ Tahun 2020 } \\
\cline { 2 - 9 } & Kuantitas & Satuan & Kuantitas & Satuan & Kuantitas & Satuan & Kuantitas & Satuan \\
\hline Operasional & 690 & Liter/ & 575 & Liter/ & 423 & Liter/ & 300 & Liter/ \\
BBM (Solar) & & bulan/ & & bulan/ & & bulan/ & & bulan/ \\
& & orang & & orang & & orang & & orang \\
\hline Operasional & 125 & Liter/ & 100 & Liter/ & 50 & Liter/ & 25 & Liter/ \\
BBM untuk & & tahun/ & & tahun/ & & tahun/ & & tahun/ \\
Perbaikan & & orang & & orang & & orang & & orang \\
Kapal ke luar & & & & & & & & \\
Daerah & & & & & & & & \\
\hline
\end{tabular}

Gambar 1. Penggunaan BBM nelayan selama 4 tahun berturut-turut

Dalam rangka responsifitas terhadap dampak pandemi Covid-19, PT PHM melakukan optimalisasi program NELAYANKU HEBAT melalui diversifikasi kegiatan. Sasaran optimalisasi ditujukan kepada istri nelayan agar dapat membantu menopang perekonomian keluarga nelayan. Hasil pemetaan sosial yang menjadi basis program ini menyebutkan bahwa Desa Muara Pantuan dan Desa Sepatin memiliki potensi sumber daya perikanan tambak udang. Syarat yang harus dipenuhi agar udang yang telah dipanen dapat dijual kepada pengepul adalah dengan memisahkan bagian kepala udang dengan badannya. Selama ini masyarakat menganggap bahwa kepala udang merupakan limbah yang harus segera dibuang karena cepat membusuk.

Dari sudut pandang berbeda, PT PHM menilai limbah kepala udang dapat diolah menjadi produk ekonomis. Argumentasi PT PHM kemudian dikuatkan oleh kajian ilmiah Universitas Mulawarman mengenai pengolahan limbah kepala udang menjadi petis dan kaldu bubuk. Kerja sama yang terjalin antara dua aktor tersebut menghasilkan kegiatan pelatihan pemanfaatan limbah kepala udang menjadi produk petis dan kaldu bubuk. Pelatihan ini diikuti oleh istri nelayan dan kalangan perempuan lain.

Keterampilan membuat kaldu dan petis bubuk dari kepala udang menjadi hal baru bagi mereka. Setelah memiliki ragam kapasitas dalam mengolah produk hasil perikanan, istri nelayan berinisiatif membentuk dua kelompok Usaha Kecil Menengah (UKM) yang didalamnya turut mengikutsertakan kalangan perempuan lain yang bukan dari keluarga nelayan. Dengan demikian kelompok binaan PT PHM pada program NELAYANKU HEBAT bertambah menjadi 15 kelompok. Adapun rinciannya terdapat pada Tabel 1 .

Tabel 1. Kelompok binaan PT PHM pada program NELAYANKU HEBAT bertambah menjadi 15 kelompok.

\begin{tabular}{clc}
\hline No & \multicolumn{1}{c}{ Nama Kelompok } & $\begin{array}{c}\text { Jumlah } \\
\text { Anggota }\end{array}$ \\
\hline 1 & KUB Pantuan Jaya & 13 Oang \\
2 & KUB Rumpon Setia & 10 Orang \\
3 & KUB Rumpon Sejati & 13 Orang \\
4 & KUB Tunas Harapan & 14 Orang \\
5 & KUB Lumayan & 13 Orang \\
6 & KUB Maju Bersama & 10 Orang \\
7 & KUB Karya Bersama & 13 Orang \\
8 & KUB Karya Bersaudara & 28 Orang \\
9 & KUB Salba Utama & 10 Orang \\
10 & KUB Sejahtera & 13 Orang \\
11 & KUB Sinar Bahari & 21 Orang \\
12 & KUB Karya Bersatu & 14 Orang \\
13 & UKM Teratai Pesisir & 20 Orang \\
14 & UKM Wanita Kreatif & 21 Orang \\
15 & UKM Lestari & 15 Orang \\
Jumlah & 228 Orang \\
\hline
\end{tabular}

\section{Aspek Planet}

Program NELAYANKU HEBAT yang menerapkan praktik nelayan tangkap ramah lingkungan turut memberi dampak positif bagi lingkungan sekitar Desa Muara Pantuan dan Desa Sepatin. Terdapat tiga poin penting impact dari program NELAYANKU HEBAT (Gambar 2). 
Implementasi Praktik Corporate Social Responsibility PT Pertamina Hulu Mahakam Melalui Program Pemberdayaan Nelayan

\begin{tabular}{|c|c|c|c|c|c|c|c|c|}
\hline \multirow[b]{2}{*}{ Uraian } & \multicolumn{2}{|c|}{ Tahun 2017} & \multicolumn{2}{|c|}{ Tahun 2018} & \multicolumn{2}{|c|}{ Tahun 2019} & \multicolumn{2}{|c|}{ Tahun 2020} \\
\hline & Kuantitas & Satuan & Kuantitas & Satuan & Kuantitas & Satuan & Kuantitas & Satuan \\
\hline $\begin{array}{l}\text { Emisi Gas } \\
\text { Carbon } \\
\left(\mathrm{CO}_{2}\right)^{* *}\end{array}$ & 22087,73 & $\mathrm{kgCO}_{2}$ & 18046,4 & $\mathrm{~kg} \mathrm{CO}_{2}$ & 13540,74 & $\mathrm{~kg} \mathrm{CO} 2$ & 9603,36 & $\mathrm{~kg} \mathrm{CO} 2$ \\
\hline $\begin{array}{l}\text { Emisi Gas } \\
\text { Carbon } \\
\left(\mathrm{CO}_{2}\right)^{* *}\end{array}$ & 22,087 & ton $\mathrm{CO}_{2}$ & 18,046 & ton $\mathrm{CO}_{2}$ & 13,54 & ton $\mathrm{CO}_{2}$ & 9,60336 & ton $\mathrm{CO}_{2}$ \\
\hline $\begin{array}{l}\text { Hasil } \\
\text { Tangkapan } \\
\text { Ikan Kecil } \\
\text { Yang Dibuang }\end{array}$ & NA & $\mathrm{NA}$ & 254 & $\begin{array}{c}\mathrm{Kg} / \text { bulan } \\
\text { /kelomp } \\
\text { ok }\end{array}$ & 156,8 & $\begin{array}{l}\mathrm{Kg} / \text { bulan/ } \\
\text { kelompok }\end{array}$ & 75 & $\begin{array}{l}\mathrm{Kg} / \text { bulan/ } \\
\text { kelompok }\end{array}$ \\
\hline $\begin{array}{l}\text { Penyelamatan } \\
\text { Mangrove }\end{array}$ & NA & Hektar & $\mathrm{NA}$ & Hektar & NA & Hektar & 10,8 & Hektar \\
\hline
\end{tabular}

**Perhitungan berdasarkan 2006 IPCC Technical Guidelines for National Greenhouse Gas Inventories

Gambar 2. Hasil perhitungan berdasarkan data absolut terukur program NELAYANKU HEBAT

Pertama, aktivitas nelayan yang menjadikan rumpon sebagai alat bantu tangkap ternyata meninggalkan persoalan lingkungan. Sebelum ada intervensi PT PHM, bahan dasar pembuatan rumpon diambil dari tanaman mangrove. Setidaknya untuk membuat satu buah rumpon membutuhkan lebih dari sepuluh batang pohon mangrove. Apabila populasi nelayan di salah satu desa lebih dari 50\%, maka penebangan magrove menjadi sangat masif. Terlebih setiap tiga bulan sekali akan dilakukan pembuatan rumpon baru untuk menimpa rumpon lama yang telah lapuk.

Kepedulian PT PHM untuk menyelamatkan vegetasi mangrove diwujudkan dalam bentuk bantuan rumpon ramah lingkungan yang berbahan dasar besi dan beton. Secara perlahan nelayan diberikan edukasi mengenai larangan dan resiko akibat eksploitasi mangrove. Melalui bantuan rumpon ramah lingkungan, dalam jangka pendek nelayan tidak perlu lagi memperbaharui rumpon. Meskipun untuk merubah pola perilaku nelayan membutuhkan waktu lama, PT PHM secara rutin melakukan monitoring dan evaluasi program.

Awal mula pengenalan rumpon ramah lingkungan kepada kelompok nelayan sempat dilakukan penolakan. Karena sejak turuntemurun rumpon selalu berbahan dasar mangrove. Saat itu, hanya beberapa orang binaan saja yang mencoba membuat rumpon ramah lingkungan. Untuk memberikan keyakinan kepada kelompok nelayan terhadap keberhasilan rumpon ramah lingkungan, PT PHM bekerja sama dengan tim penyelam untuk melakukan pemantauan rumpon di dasar laut.
Hasil dari penyelaman menyebutkan bahwa terdapat perbedaan penilaian antara rumpon berbahan dasar mangrove, bambu dan besi. Secara kontruksi, rumpon besi lebih tahan lama dibanding mangrove dan bambu. Sumber daya ikan yang berada di sekitar rumpon besi pun lebih banyak dengan 30 spesies, mangrove 26 spesies, dan bambu 18 spesies. Rekaman video bawah laut menjadi bukti valid keberhasilan rumpon ramah lingkungan. Perlahan mulai banyak nelayan lain yang tertarik membuat rumpon besi.

Kedua, aktivitas nelayan yang merusak lingkungan adalah tingginya intensitas penggunaan pukat harimau. Pukat harimau atau trawl adalah semacam pukat kantong yang dioperasikan dengan cara ditarik pada jarak yang panjang agar ikan-ikan masuk ke dalam jaring. Pelarangan alat tangkap pukat harimau didasarkan pada Peraturan Menteri (Permen) Nomor 02 Tahun 2015, karena merusak lingkungan, menghancurkan terumbu karang dan ikan-ikan kecil ikut terjaring sehingga kelangsungan hidup ikan terancam.

Sejak bantuan rumpon diberikan dan edukasi intensif kepada nelayan, intensitas penggunaan pukat harimau terus mengalami penurunan. Jika dikomparasikan rumpon memiliki kelebihan dibanding pukat harimau. Adapun kelebihannya adalah sebagai berikut:

a. Rumpon merupakan alat bantu tangkap. Sedangkan pukat harimau adalah alat tangkap yang dilarang oleh pemerintah.

b. Pukat harimau dapat menghancurkan terumbu karang yang menjadi habitat ikan. Sedangkan rumpon justru menyediakan alternatif habitat bagi ikan. 
c. Pukat harimau menyebabkan ikan-ikan kecil ikut terjaring yang menyebabkan kelangsungan hidup ikan terancam. Sedangkan rumpon dapat dijadikan sebagai tempat ikan untuk bertelur.

Ketiga, pengurangan penggunaan BBM nelayan untuk operasional dan perbaikan kapal ke luar daerah berimplikasi terhadap penurunan emisi gas karbon. Gas karbon dioksida $\left(\mathrm{CO}_{2}\right)$ adalah faktor utama yang menyebabkan pemanasan global. Upaya perlindungan lingkungan melalui program NELAYANKU HEBAT sejalan dengan tujuan pembangunan berkelanjutan poin 13 tentang penanganan perubahan iklim.

\section{SIMPULAN DAN SARAN}

Program NELAYANKU HEBAT merupakan bagian praktik CSR yang dilakukan oleh PT PHM. Selain untuk menjawab persoalan operasi perusahaan, poin penting CSR yakni untuk membantu pemerintah mengentaskan masalah lingkungan, social dan ekonomi. Berdasarkan hasil evaluasi manfaat yang dirasakan nelayan dari program ini antara lain nelayan mampu meningkatkan perekonomian dengan menekan beban pengeluaran operasional, kaum perempuan menjadi produktif dalam menopang kebutuhan primer keluarga, kawasan hutan mangrove tetap terjaga, dan yang terpenting resiko kecelakaan (ledakan pipa) dapat diminimalisir. Selanjutnya, kegiatan program akan berfokus terhadap rintisan destinasi wisata pancing di Desa Muara Pantuan dan Desa Sepatin. Melalui kegiatan pariwisata diharapkan tercipta multiplier efek. Pada akhirnya aktivitas perekonomian di tingkat lokal meningkat.

Teknik manajemen konflik yang dilakukan PT PHM dapat dijadikan rujukan bagi perusahaan lain yang mengalami hal serupa. Impementasi tanggung jawab sosial harus bersifat komprehensif yang tidak hanya berfokus pada keuntungan perusahaan semata. Maka dari itu sebelum menerapkan praktik
CSR, diperlukan diskusi lintas aktor sebagai jembatan awal terbentuknya program. Setelah itu, selama proses program berjalan kegiatan pendampingan, monitoring dan evaluasi secara berkala perlu dilakukan untuk mempertahankan dan meningkatkan kemajuan program.

\section{UCAPAN TERIMA KASIH}

Terima kasih kami ucapkan kepada PT Pertamina (Persero), PT Pertamina Hulu Indonesia, Dinas Kelautan dan Perikanan Provinsi Kalimantan Timur, Dinas Kelautan dan Perikanan Kabupaten Kutai Kartanegara, Universitas Gadjah Mada, Institut Teknologi Kalimantan, dan Universitas Mulawarman atas dukungannya dalam perencanaan, implementasi dan evaluasi program NELAYANKU HEBAT.

\section{DAFTAR PUSTAKA}

Aini, A.I., Khaudli, M.I, \& Suprapto, R. (2018). Pemberdayaan Ekonomi Masyarakat Melalui Pemasaran Wisata Kuliner Jajanan Tradisional di Desa Cantuk Kabupaten Banyuwangi. Engagement: Jurnal Pengabdian Kepada Masyarakat, 2(2), 168175.

https://doi.org/10.29062/engagement.v2i2.3 6

Arowoshegbe \& Emmanuel. (2016). Sustainable and Triple Bottom Line: An Overview of Two Interrelated Concepts. Igbinedion University Journal of Accounting, vol.2, 88126.

Devito, J.A. (1997). Komunikasi Antar Manusia: Kuliah Dasar. Jakarta: Professional Books.

Sugiyono. (2001). Metode Penelitian Pendidikan. Bandung: Alfabeta.

Suparlan, P. (1994). Metode Penelitian Kwalitatif. Jakarta: Program Kajian Wilayah Amerika-Universitas Indonesia. 